\title{
Halfway there: the struggle to manage conflicts of interest
}

\author{
Arthur L. Caplan
}

Department of Medical Ethics and Center for Bioethics, University of Pennsylvania, Philadelphia, Pennsylvania, USA.

\begin{abstract}
Conflicts of interest are known to create problems for the integrity of biomedical research. The editors of the JCI have set out a rigorous policy to help manage conflicts. But they focus only on financially generated conflicts. Here I identify other sources of conflict and offer some suggestions for their management.
\end{abstract}

Could there be any more treacherous terrain for an editorial board to enter these days than conflict of interest? The mere mention of the subject suffices to elicit from scientists and researchers groans, rolled eyes, pursed lips, and not a few imprecations - the cataloguing of which, while eye-opening, will never appear in the pages of this or any other prestigious biomedical journal. Yet the new editors have chosen to set out a conflictof-interest policy regarding financial conflicts that goes further than any other I am familiar with.

Not only have the new editors set out guidelines for authors, but they have imposed standards upon themselves and upon reviewers as well (1). While one can quibble about the dollar amounts that trigger concern, the fact that the new policy not only enters into the terrain of financial conflict but pioneers new frontiers in terms of scope and precision is nothing but commendable. That said, the policy set out in this issue will not prove adequate. No policy focused solely on financial conflict could.

Money is an important source of conflict: study after study has shown the power that money can have in the publication of scientific findings (2-6). The new JCI policy rightly attempts to limit the pull that a financial stake can create in decisions to publish a manuscript, interpret data in a positive light, or omit data and interpretations that are less than flattering to personal bottom lines.

The problem is that there are more sources of conflict of interest than money, and these conflicts are mentioned only briefly in the second tier of the new JCI policy. Some of the most notorious scandals in the biomedical sciences in recent years have been fueled as much by the desire for fame or to be first as by financial return. The greatest fraud in the recent history of science - the claim to have created viable stem cell lines from cloned human embryos - was influenced by many factors, but money was not among them (7).

Not only does ambition create conflict, but so do politics, personal rivalries, the lust for power, institutional pressures, the drive to secure tenure, the desire for prizes and awards, and even the desire simply to please one's peers. The new policy is silent about these types of conflicts of interest, but they most certainly exist.

So what are the editors of the JCI to do? Return to the current policy at a later date and amend it? Ought they require that in addition to financial disclosures, all editors, contributors,

Conflict of interest: A.L. Caplan is the Chair of the Bioethics Advisory Panel at GlaxoSmithKline, a member of the Scientific Advisory Board at Tengion, and a member of the Scientific Advisory Board at Octagon Research Solutions Inc. He has received honoraria from Genentech, Siemens, and the Susan B. Komen Breast Cancer Foundation. Citation for this article: J. Clin. Invest. 117:509-510 (2007). doi:10.1172/JCI31565. and reviewers submit biographies and psychological profiles on themselves to be published in tiny agate type? Should the editors, in the name of rooting out nonfinancial conflicts of interest, publish all possible facts about authors', reviewers', and editors' tastes, religious views, political affiliations, sexual orientation, churchgoing habits, intrafamilial rivalries, and graduate school grudges? Soon the JCI would consist of little but endless, difficult-to-read autobiographies!

The answer to the question of how to deal with all forms of conflict of interest is not disclosure or transparency; rather, it requires integrity. But even integrity is not sufficient. Since the days when journals first appeared, editors realized that something else was required.

The antidote to fame, power, politics, and greed seized upon by journals in the twentieth century was vigorous peer review. Adherence to proven scientific methods, insistence on rigorous scientific design, close attention to statistical analyses, and demanding that interpretation not wander too far away from data are the hallmarks of sound peer review. Yet in the increasingly busy world of science, there is less and less time for peer review. What can be done to encourage this dimension of managing conflict of interest?

First, authors must understand that their papers will be subject to vigorous peer review, including the possibility that raw data will have to be provided to a reviewer. All authors should agree that if asked, they will make this data promptly available.

Second, editors should not only thank peer reviewers but should give consideration to publishing their reviews online after a sufficient period of time has lapsed after the publication or rejection of a paper. Currently, peer review is blind, but that is not completely a good thing. Confidential reviewing may give reviewers the cover to say what they wish, but blind review is still impossible for outsiders to see and understand. Anonymity need not be extended in perpetuity. Thought needs to be given to making reviews available in some form so that potential authors know what reviewers expect, reviewers can learn from one another, those new to reviewing can see what is expected, and those who do a poor job can be held accountable. Editors do some of these things, but readers and other reviewers should be allowed a role in the process as well.

Peer reviewing should also become part of the process of gaining promotion - not just an aspect of service but an expected and honored part of what it means to enter into the community of biomedicine and science. If you cannot do a competent peer review of a paper in your field, then should you really be moving ahead in that field? Senior leaders in the field must do their duty and show younger members that peer review is not meant simply for the young.

Editors may also need to spend a bit more of their admittedly meager budgets to try and retain more professional expertise in 
technical areas of review. Some journals now do this, and it makes sense. Math and statistics are not for rank amateurs, but they sometimes are handled by nonexperts even at the highest level of peer review in major biomedical journals.

Last, the editors may want to supplement print publication with an occasional online illustration of the discussion that takes place around the acceptance or rejection of a particular paper. Some anonymity is in order, but the door to the star-chamber of editorial board decision making could be opened slightly to let the masses see what goes on in weighing reviews, editorial judgment, and the desire to get the latest hot paper or author. Peer review is best when, in the phrase used to describe the attitude held by Henry Oldenburg, one of its first proponents, and the first editor of the Royal Society of London's Philosophical transactions, it permits “. . . knocking men's heads together to make the intellectual sparks fly ... that the truth might emerge from the conflict of rival views" (8).

1. Neill, U.S., Thompson, C.B., Feldmann, M., and Kelley, W.N. 2007. A new JCI conflict-of-interest policy. J. Clin. Invest. 117:506-508. doi:10.1172/ JCI31587.

2. Lesser, L.I., Ebbeling, C.B., Goozner, M., Wypij, D. and Ludwig, D.S. 2007. Relationship between funding source and conclusion among nutrition-related scientific articles. PLoS Med. 4:e5. doi:10.1371/ journal.pmed.0040005.

3. Levine, J., Gussow, J.D., Hastings, D., and Eccher, A.
The more heads let into the process of peer review, the more the process is valued. The more the heads are trained to undertake the process, the more the truth will emerge.

This is asking a lot. But conflict of interest is a tough problem. The editors of the JCI have shown themselves willing not to shy away in the face of the most miserable aspect of the problem: money. Transparency and disclosure are the weapons they have aggressively deployed. Peer review is the other great protection against conflicts of interest. It has weakened over the years. The editors, readers, contributors, and reviewers for this journal should give some consideration to whether my suggestions or others could help strengthen it.

Address correspondence to: Arthur L. Caplan, Department of Medical Ethics and Center for Bioethics, University of Pennsylvania, 3401 Market St., Suite 320, Philadelphia, Pennsylvania 19104, USA. E-mail: caplan@mail.med.upenn.edu.
2003. Authors' financial relationships with the food and beverage industry and their published positions on the fat substitute olestra. Am. J. Public Health. 93:664-669.

4. Brennan, T.A., et al. 2006. Health industry practices that create conflicts of interest: a policy proposal for academic medical centers. JAMA. 295:429-433.

5. Mahowald, M.W., and Cramer M.A. 2005. What? Influenced by industry? Not me! Sleep Med.
6:389-390

6. Newberger, A., and Caplan, A.L. 2006. Taking ethics seriously in cosmetic dermatology. Arch. Dermatol. 142:1641-1642.

7. Caplan, A.L. 2007. Smart mice, not-so-smart people: an interesting and amusing guide to bioethics. Rowman \& Littlefield Inc. Lanham, Maryland, USA. 240 pp.

8. Hall, A.R., and Hall, M.B. 1962. Why blame Oldenburg? Isis. 53:482-491. 